\title{
US air pollution rules stir up a stink about research
}

[WASHINGTON] The decision last week by President Bill Clinton to approve controversial new US regulations on air pollution despite opposition from industry and some of his own economic advisers - is expected to provoke a congressional challenge when the rules are published later this month.

Ironically, it may also give scientists something they have been requesting for years: more government spending on research to reduce the scientific uncertainties surrounding the effects on health of ozone and small airborne particulate matter. That uncertainty helped to fuel months of rancorous debate, with each side accusing the other of "junk science", and researchers being caught in the political crossfire.

Clinton endorsed regulations only slightly looser than those proposed by the Environmental Protection Agency (EPA) last November (see Nature 384, 392; 1996). The 24-hour allowable standard for fine particulate matter (2.5 microns and smaller) will be set at 65 instead of 50 micrograms per cubic metre. Ozone polluters will be charged after the fourth time they exceed acceptable levels rather than the third. And municipalities will not have to comply with the new rules for at least seven or eight years.

The EPA administrator, Carol Browner, said that it will take up to five years just to set up a monitoring network for fine particles, which are not regulated at present. The delay, she said, "gives us a chance to make sure that all the science is made use of and is thoroughly reviewed".

Some scientists, frustrated at the perennial lack of funding for research in this area, believe that issuing a regulation now, even with many gaps in our understanding of the health effects of the pollutants, may be the only way to stimulate greater investment. Joe Mauderly of the Lovelace Respiratory Research Institute in Albuquerque, New Mexico, who chairs EPA's Clean Air Scientific Advisory Committee (CASAC), told Congress last March: "I think it's unfortunate, but probably reality, that information [on particulates] will not be collected unless a standard is promulgated.'

\section{President of UN summit 'sobered' by outcome}

[WASHINGTON] A special

session of the United Nations general assembly closed in New York last week with few signs of progress towards the goals agreed at the 1992 Earth Summit in Rio de Janeiro, and a growing sense that nations are reluctant to pay anything more than lipservice to them.

The session was marked by both its high level of attendance - the leaders of most of the world's leading economies delivered speeches - and low expectations, with little progress anticipated or achieved. But even these expectations were dashed when the parties failed to agree on a broad-ranging 'political statement' intended to point the way towards meeting the Rio goals.

The meeting ended instead with prolonged negotiations to produce a more lengthy and detailed programme for the further implementation of Agenda 21, the document agreed at Rio.

The president of the session, Ismail Razali of Malaysia, admitted that "the overall results" of the special session were "sobering". Environmentalists went further. "The political statement, which was supposed to be a wake-up call to the world, has been abandoned," says Bill Hare of Greenpeace, the environmental group. "This is verging on a disaster. It isn't clear what credibility this entire process has left."

Officials at the UN pointed out that some progress was made, with agreement for the first time to phase out lead in petrol worldwide, for example, and plans to establish mechanisms for global action on freshwater and forestry conservation.

But this headway was overshadowed by public deadlock on the issue of global warming. Pressure from Europe and the small island states failed to extract specific promises from Japan or the United States on cuts in greenhouse gas emissions.

Last Thursday (26 June), US President Bill Clinton told the meeting that he would take action "to convince the American people and the Congress that the climate change problem is real and imminent". He added that he would bring to December's meeting at Kyoto, Japan, where countries hope to negotiate a treaty on greenhouse gas emissions, "a strong American commitment to realistic and binding limits that will significantly reduce our emissions of greenhouse gases".

The US administration has yet to decide what kind of limit it will pursue at Kyoto. It may seek anything from 10 per cent below to 10 per cent above 1990 emission levels by 2010 , according to one environmentalist.

Colin Macilwain

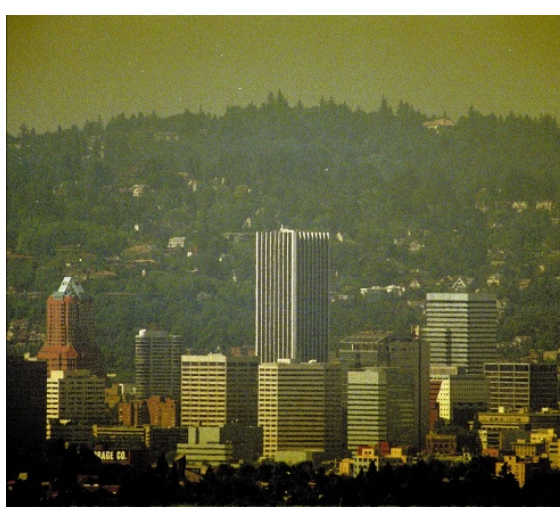

Hazy view: scientists lack funding for research on smog (above) and other pollution problems.

The message may finally be getting through. On the same day that Clinton endorsed the regulations, a House of Representatives appropriations subcommittee added \$40 million for ozone and particulates research, on top of the $\$ 45$ million the administration had already requested for 1998. But not all the increase would necessarily go to EPA. The subcommittee called for the National Institute of Environmental Health Sciences, part of the National Institutes of Health, to become involved in distributing the research money.

Others in Congress say they will fight the new regulations. One option would be for Congress to test its new authority to veto individual regulations. Another would be simply to hold up EPA funds for implementing the rules through the appropriations process.

Some scientists are still smarting from political tactics used during the debate. The House Commerce Committee chairman, Thomas Bliley (Republican, Virginia), who opposes tighter regulations, has been putting pressure on Douglas Dockery of the Harvard School of Public Health and his colleagues to release raw data from a study showing increased sickness and death from exposure to particulate matter.

When EPA joined in the request last spring, the Harvard team argued that releasing questionnaires containing personal data about respondents would violate confidentiality agreements. But Harvard finally agreed to an independent reanalysis of the Harvard study, with controlled access to the questionnaires. This will be done by a panel of scientists convened by the Health Effects Institute in Cambridge, Massachusetts, which is funded jointly by EPA and industry.

The institute sponsored a workshop last week to determine how the reanalysis of this and two other studies on the health effects of particulates will be done. But that has scarcely toned down the rhetoric. Paul Beckner, president of the pro-industry Citizens for a Sound Economy, said last week: "In the interest of truth, we call on the administration to make public the secret data that the EPA has long claimed justifies its proposal." TonyReichhardt 